Berkers, Pauwke \& Merel Eeckelaer. 2014. Rock and roll or rock and fall? Gendered framing of the rock and roll lifestyles of Amy Winehouse and Pete Doherty in British broadsheets. Journal of Gender Studies 23(1): 3-17.

http://www.tandfonline.com/doi/full/10.1080/09589236.2012.754347\#.U5gN-LRpP2k

\title{
Rock and roll or rock and fall? Gendered framing of the rock and roll lifestyles of Amy Winehouse and Pete Doherty in British broadsheets
}

Pauwke Berkers (berkers@eshcc.eur.nl)

Department of Art and Culture Studies (ESHCC), Erasmus University Rotterdam

\section{Merel Eeckelaer}

\begin{abstract}
Combining insights from gender, popular music, and celebrity studies, this article addresses to what extent British broadsheets frame Amy Winehouse and Pete Doherty differently with regard to their rock and roll lifestyle. Our content analyses of The Guardian and The Independent indicate clear gender differences. First, Doherty's excessive behavior is often framed in positive terms (rock and roll), while the media discuss Winehouse's conduct more negatively (rock and fall). Second, British newspaper journalists admire Doherty's courage to lead such a lifestyle, oftentimes justifying - or even negating - his behavior, arguing he is an independent individual or even a hero. Such adoration is absent when Winehouse's escapades are reported on; most articles treat her as a victim, expressing concern regarding her poor health. As such, our findings show how music journalists use relational complicit practices - admiration/justification/negation of male and victimization of female enactment of hegemonic masculinity - to maintain masculine monopoly over the archetypical rock and roll lifestyle.
\end{abstract}




\section{Introduction}

On 23 July 2011 Amy Winehouse tragically died as a result of excessive alcohol abuse. One group of media commentators was quick to blame her death on her inability to manage a selfchosen rock and roll lifestyle. For example, The Independent stated: 'There's no point seeking someone to blame - Winehouse's extraordinary insecurity lay at the heart of her troubles' (24 July 2011). In line with post-feminism, women are expected to be autonomous neo-liberal subjects, responsible for their individual success. However, this particular set of practices - sex, drugs, and rock and roll - has been naturalized as highly masculine (Frith and McRobbie 1990, Schippers 2002). In the absence of any radical adjustments to the gender hierarchy, women are still likely to fail to secure individual success, leading to a disordered - yet normalized - femininity (Gonick 2006, McRobbie 2009). Few studies have addressed whether women are sanctioned for enacting masculinity in the form of a 'rock and roll' lifestyle whereas men rewarded as an exemplar of hegemonic masculinity (Wetherell and Edley 1999, Schippers 2007).

A second group of journalists suggested that the (tabloid) media - at least partly contributed to the death of Amy Winehouse. For example, The Guardian wrote about 'the female counterpart to Pete Doherty': 'To read tabloid journalists berating the drug dealers for their part in Winehouse's death is to hear the sound of a pot calling the kettle, if not black exactly, then certainly kitchen-based' (27 July 2011). As a consequence of a competitive newspaper market and the extraordinary growth of celebrity culture (Turner 2004, Schlesinger 2006), British broadsheets also paid extensive attention to both performers' rock and roll lifestyle. As broadsheets target the governing and business elite, they are likely to affect if (and how) other media and society in general discuss a particular topic (Janssen et al.2008).1 Yet, we know little about how elite media cover rock and roll celebrities in relation to different (classed) masculinities (cf. Eastman 2012), even though popular music is a key site of masculinity (Clawson 1999). 
So this article addresses to what extent, and in what ways, British broadsheets have framed Amy Winehouse and Pete Doherty differently in relation to their rock and roll lifestyle. In answering this question, we aim to make several contributions to gender studies, popular music scholarship, and, to a lesser extent, celebrity studies. First, most studies within the above-mentioned fields have failed to take intergender relations into account. Popular music and celebrity scholars have primarily focused on women only (Davies 2001, Gies 2011), whereas studies of masculinities dominate contemporary gender scholarship (Wedgwood 2009, Finley 2010). In both cases it remains unclear to what degree female artists are treated differently compared to their male counterparts. Second, as only a minority of men enacts hegemonic masculinity (exemplars), complicit practices are crucial in actively maintaining the gender hierarchy (Connell 1995). While previous research has primarily examined ordinary men, this article examines if and how the (elite) media - providing a pervasive repertoire on how to do gender - practice complicit masculinity (Jarman-Ivens 2007).

We undertook a systematic case study, comparing the newspaper coverage of British artists Amy Winehouse and Pete Doherty. Both performers were highly successful in terms of critical acclaim and chart success (see Bourdieu 1993), particularly in the United Kingdom. In addition, their rock and roll lifestyles - including alcohol and drug abuse, sexual escapades, fights, and legal problems - have been widely chronicled in the British media (Shaw et al.2010). Using both quantitative and qualitative content analysis, we examined newspaper articles that appeared in The Guardian and The Independent about both artists from January 2004/2006 to January 2009 (see Methods section). Partly based on previous studies, we deduced five rock and roll frames (living on the edge, hero, independent individual, authenticity, and success) and five rock and fall frames (concern, cannot deliver, media victim, dependent individual, and crazy). Journalists employ such frames to make particular aspects of the story salient, while backgrounding other elements (Entman 1993), based on whether they resonate among their intended audience (Binder 1993). Therefore the media framing of Winehouse and Doherty might 
tell us what a dominant segment of society considers appropriate behavior for women as well as men.

\section{Theorizing gender}

In recent decades an essentialist conception of gender as a stable set of ascribed personality traits ('gendered person' approach) has been superseded by an interaction-based view known as 'doing gender' (West and Zimmerman 1987, 2009). This perspective focuses on how gender is accomplished through the everyday interactions of men and women with reference to normative conceptions of what constitutes appropriate behavior for one's sex category (West and Zimmerman 1987, Poggio 2006). Below we will discuss how this study contributes to gender scholarship by addressing intergender relations, accountability and masculinities, and complicit practices.

First, reciprocal interactions between men and women are affected by intergender (power) relations, that is, the structural subordination of women and the dominance of men. Successful ways of 'being a man' - hegemonic masculinity 2 - consist of situated practices actively constructed in a hierarchical relation vis-à-vis different femininities (Connell 1995, Beynon 2002). Feminine quality characteristics - including physical vulnerability, passivity, or compliance - are symbolically posited as complementary and inferior ('emphasized femininity') to the masculine traits of physical strength, aggression, or authority - hegemonic masculinity (Schippers 2007). As such, the gender hierarchy is maintained by a dual dynamic: rewarding men for enacting hegemonic masculinity and at the same time sanctioning women for exhibiting similar conduct. However, whereas recent gender scholarship has largely overlooked the role of femininities in gender dynamics (Wedgwood 2009, Finley 2010), popular music studies have mostly focused on women only, researching, amongst other things, how the music press denigrates the work of female artists (Davies 2001). As understanding masculinities requires attention to femininities (Martin 2001, Connell and Messerschmidt 2005), this research addresses 
intergender relations by comparing the newspaper framing of a relatively comparable male and female artist that both enacted masculine practices - the rock and roll lifestyle.

Second, masculinities and femininities are held accountable to dominant local - as well as global - intragender relations. Accountability pressures prompt people to do gender appropriate to the context, rejecting a claim that 'free will' in the form of unfettered choice ('wanting to') is the reason people practice gender (Martin 2003, p. 358). Therefore we must consider the social settings, each with its own embedded type of hegemonic masculinity and patriarchal dividends, in which gender is enacted (Connell and Messerschmidt 2005). In alignment with increasing economic globalization and neo-liberalism, transnational business masculinity is often considered the globally dominant form of masculinity (Connell 1998, Connell and Wood 2005). Business masculinity is characterized by authority (or control over subordinates) based on the impersonal and technical rationality of management (Kerfoot and Knights 1998). Although not dominating all societal domains, 'local' masculinities need to be analyzed in relation to the global dominance of this upper-middle-class definition of masculinity (Knoppers and Anthonissen 2005), something which few studies have done (Beynon 2002).

Third, hegemonic masculinity - and therefore the gender hierarchy in general - needs continuous and active maintenance work. Since only a minority of men actually enacts hegemonic masculinity (that is, are in the 'front line'), exemplars of masculinity function as authoritative symbols of the ideals, fantasies, and desires of 'ordinary' men (Connell and Messerschmidt 2005). Previous studies have focused on the complicit practices of ordinary men, for example football fans (Connell 1995), construction workers (Iacuone 2005), and girl-hunting students (Grazian 2007). In contemporary celebrity culture, however, the media play a central role in providing ordinary men exemplars of hegemonic masculinity as potential role models to emulate (Schrock and Schwalbe 2009). By mobilizing affiliating masculinities the media are involved in complicit homosocial practices, oftentimes unintentionally upholding male 
domination (Sedgwick 1985, Martin 2001). However, fine-grain studies of how complicit masculinity plays out in the media are scarce (Wetherell and Edley 1999, Jarman-Ivens 2007).

\section{Rock masculinity, accountabilities, and complicit media practices}

Before addressing if and how broadsheet media practice accountability regarding the behavior of Amy Winehouse and Pete Doherty, we will first describe the characteristics of rock masculinity. Within the field of popular music, notions of masculinity and femininity have been closely aligned with rock and pop respectively. Rock music has historically been constructed as a form of male rebellion against female domesticators and the ideology of romance (Frith and McRobbie 1990). Women were mainly regarded as passive and private consumers of allegedly slick and prefabricated - hence, inferior - pop music (Coates 1997, p. 52), excluding them from participating as high-status rock musicians (Frith 1983). Whereas pop artists 'celebrate and embrace rituals of heterosexual love, romance and commitment' (Schippers 2002, p. 24), rock artists are 'the men who take to the streets, take risks, live dangerously and, most of all, swagger untrammeled by responsibility, sexual and otherwise' (Frith and McRobbie 1990, p. 374). The rock and roll lifestyle - being a musician, having anonymous sex with countless women, and excessive alcohol or drug use (Schippers 2002) - embodies a 'locally' hegemonic type of masculinity, which broadsheet journalists might either embrace or reject depending on whether they believe it resonates among their (elite) readers (see Methods section).

First, broadsheet journalists might hold both artists accountable in reference to the rock masculinity described above. On the one hand, men who practice a rock and roll lifestyle are likely to be rewarded - or at least condoned - for legitimating hierarchical gender relations. While oftentimes only liminally aware of the consequences, male journalists 3 - many of them aspiring to be rock musicians themselves (Gudmundsson et al.2002) - mobilize affiliating masculinities by linking (mediating between) exemplars of hegemonic masculinity to their (male) readership (Sedgwick 1985, Martin 2001, 2006). On the other hand, women who enact a rock and 
roll lifestyle deviate from emphasized femininity by refusing to complement hegemonic masculinity (Schippers 2007). As they threaten intergender relationality and consequently male dominance, these women are likely to be sanctioned for performing unfeminine behavior (that is, not being 'pop'), making the archetypical rock and roll lifestyle (symbolically) unavailable to women.

Focusing on women only, previous studies have indeed shown that music critics often act more like 'men' than as journalists, representing female artists as women - instead of musicians comparing them to other women only (Davies 2001). Such journalism focuses on the physical appearance of female artists (Johnson-Grau 2002), marking them as the Other, (for example ‘women-in-rock' (Coates 1997)), or dismissing feminine pop music altogether (McLeod 2002). In addition, celebrity scholars have found that female stars are more harshly criticized than their male counterparts (Gies 2011), particularly those who have been 'on a drug- or alcohol-fuelled course of self-destruction' (Williamson 2010, p. 118), judging them as unable to perform femininity ‘correctly’ (Tyler and Bennett 2010).

Second, broadsheet journalists might hold both artists accountable to transnational business masculinity, as their readers consist of, amongst others, the managerial elite (Chan and Goldthorpe 2007). Independence, authority, and self-assertiveness are important in the practice of both masculinities. Yet, business masculinity emphasizes being in control of the self and is more congruent with the discourses of the middle to upper-middle class (Knoppers and Anthonissen 2005). In contrast, rock masculinity is regarded as a working-class protest against the corporate business elite, demonstrating - by being out of control - that 'real' men cannot be controlled (Eastman 2012). This suggests that broadsheet journalists - read by the business elite - might dismiss such 'irresponsible' rock masculinity altogether, irrespective of the gender of the performer. 


\section{Methods}

Amy Winehouse (b. 1983, London) and Pete Doherty (b. 1979, Northumberland) make for an interesting comparison for several reasons. They were part of the same generation and born and (mainly) raised in Britain. Winehouse supposedly had a 'normal family upbringing' in a North London Jewish community (Barak 2010, p. 17). Doherty's mother reportedly 'took great pride in bringing up her children in a more middle-class environment than the one she'd enjoyed' (Yates and Samson 2005, pp. 14-15). Winehouse's debut record Frank came out in 2003; Doherty's band, The Libertines, released their first album Up the bracket in 2002. Finally, both artists were infamous for their excessive rock and roll lifestyle, particularly in Britain (Hannaford 2007). As a result, Doherty has been accused of corrupting the nation's youth by Tory leader Michael Howard (Yates and Samson 2005), while the head of the United Nations Office on Drugs and Crime linked Winehouse's drug use to disaster in Africa (Newkey-Burden 2008).

To study to what extent journalists frame Amy Winehouse and Pete Doherty differently in relation to their rock and roll lifestyle, we examined two British broadsheet newspapers: The Guardian and The Independent. Since these broadsheets target - and are read by - the educated elite in high-status (non-manual professional and managerial) occupations (Chan and Goldthorpe 2007), they are likely to have a strong impact on how other media and society in general discuss a particular topic. We limit the studied period from the year Amy Winehouse (2006) and Pete Doherty (2004) released their second albums to January 2009. While their debuts did not reach the number one spot in the British charts, their second albums Back to Black and The Libertines, respectively, were certified platinum. As a result, media interest in their personal - instead of their professional - lives also increased (Turner 2004). We did a LexisNexis search using keywords 'Amy Winehouse' and 'Pete Doherty' in order to find relevant newspaper articles. We only researched editorials that had the name of the artist in the heading. This resulted in 40 articles about Amy Winehouse and 47 discussing Pete Doherty. 
Next, we performed a qualitative content analysis of all 87 newspaper articles. We examined how journalists frame a story, that is, how they: We examined how journalists frame a story, that is, how 'they select some aspects of a perceived reality and make them more salient in a newspaper article, e.g. using particular quotes. By doing this, they promote a particular reading, causal interpretation and/or moral evaluation of that story' (Entman 1993, p. 52). These frames help receivers to process a complex reality by making some information about an item more 'noticeable, meaningful and memorable' (Entman 1993, p. 53), based on the assumed resonance among their intended readers (Binder 1993).

Our initial coding categories were loosely based on previous studies (see below). After several rounds of coding, we ended up with five rock and roll frames and five rock and fall frames. The rock and roll frames discuss the behavior of Amy Winehouse and Pete Doherty in a neutral and/or positive fashion. Journalists draw on the living on the edge frame when they romanticize the artist as someone who is willing to take a risk (Frith 1983, Reynolds and Press 1995). Some journalists depicted Pete Doherty as a heroic figure or genius (Wetherell and Edley 1999, Whiteley 2006). We refer to this theme as the hero frame. When the artist is depicted as an independent, strong-willed individual, who chooses her or his own path to follow, we coded it as the independent individual frame. Others discuss rock and roll as a real, primordial form of selfexpression (Gudmundsson et al.2002, Schmutz and Faupel 2010); we coded this as the authenticity frame. The last rock and roll frame refers to how successful the artist is, that is, when journalists primarily focus on sold-out concerts or chart positions.

The rock and fall frames have a more negative connotation. Through the concern frame a journalist expresses worries - instead of admiration - about the unhealthy lifestyle of the artist (Negra and Holmes 2008, Shaw et al.2010). Furthermore, a rock and roll lifestyle comes with consequences. Therefore, some articles state that the artist cannot deliver good music anymore due to alcohol and drug abuse. In contrast to the living on the edge frame, some journalists do not see the rock and roll lifestyle as a courageous choice, but frame the artist as a passive victim of 
the media frenzy (media victim frame). Performers are also framed as being dependent on band members, (boy)friends, or family members (Tuchman and Fortin 1984, Johnson-Grau 2002). Other articles simply mock the artist, portraying her or him as out of control, mad, or crazy (Gonick 2006, Leonard 2007).

\section{Two artists, ten frames}

Table 1 shows how often each frame is used to discuss Amy Winehouse and Pete Doherty. In general, Doherty is framed much more positively (rock and roll) than Winehouse (rock and fall). More specifically, $80.9 \%$ of the newspaper articles frame Doherty as rock and roll, whereas journalists predominantly discuss Winehouse in terms of rock and fall (60.0\% of the articles). This difference in the use of rock and roll and rock and fall frames already provides initial evidence that Doherty and Winehouse are discussed differently, pointing to gender inequality. In addition, Table 1 displays several significant differences in the extent that British journalists draw upon each of the ten frames. While Doherty is framed as an independent individual (17.0\%) or even a hero (10.6\%), who is living on the edge (40.4\%) - all rock and roll frames - journalists express their concern with regard to Winehouse's behavior $(27.5 \%)$ and the resulting failures to deliver a decent performance $(7.5 \%)$ - all rock and fall frames. However, these numbers do not tell us whether these frames are used in a gendered way, that is, how complicit masculinity works in practice. Below we will therefore present the findings of our qualitative content analysis.4

[Table 1 about here]

\section{Framing rock and roll}

\section{Living on the edge}

Pete Doherty is most frequently framed as an artist who is living on the edge $-40.4 \%$ of the articles - while only $17.5 \%$ of the newspaper stories discussing Winehouse stress this frame 
(Table 1). In general, such articles contain references to a 'live fast, die young' lifestyle which focuses solely on the present, including phrases as 'living for the day', 'dedicated to the hedonism of the here and now' (The Guardian, 4 November,2005) and 'living for the moment' (The Independent, 23 February,2005). But whereas journalists drawing on this frame - at best - merely condone Winehouse's conduct, Doherty's behavior is covered much more positively, acknowledging - to a point of near-adoration - his courage to live a rock and roll lifestyle, his willingness to take risks and 'accept the consequences' or even 'dare damnation':

Rarely have I met anybody with such courage to live life truly for the moment and accept the consequences of those actions with no fear of criticism or scorn. (The Guardian, 27 August 2005)

I was intrigued by him. Perhaps part of it was because I'm a former crack addict myself. There was a man daring damnation, I thought. (The Guardian, 25 February 2005)

Writing about the masculine rock rebellion of the 1960s, Reynolds and Press noted that 'Joplin's self destructive impulses, the basically suicidal trajectory of her lifestyle, does not have the same charismatic, Dionysian aura of other, "too fast to live, too young to die" figures from the ' 60 s like Brian Jones or Hendrix' (1995, p. 272). Forty years later their observations seem still valid. Moreover, even broadsheet journalists targeting an elite audience admire rock masculinity's embodiment of risk and neglect, even though it sharply contrasts with business masculinity's treatment of the body as thing to be managed, such as by eating healthy and jogging (Connell and Wood 2005).

\section{We could be heroes}

Not only do British broadsheet journalists romanticize Doherty's rock and roll lifestyle, $10.6 \%$ of the articles frame him as a hero. Interestingly, such framing is non-existent in articles about Amy Winehouse (Table 1). For his fans, Doherty fulfills the role of a 'rock icon' (The Independent, 5 November 2006), or an 'indie icon' (The Guardian, 14 July 14 2008), who possesses 'innate 
charisma' (The Guardian, 9 October 2004). The quote below describes how the mood amongst the audience turns into idolization when Doherty appears on stage:

When Doherty arrived for the last two numbers, the mood changed from repelled fascination to adoration. (The Guardian, 15 April 2004)

Furthermore, (male) journalists themselves oftentimes seem to worship Doherty, acting as 'enlightened fans' (Gudmundsson et al.2002, p. 60):

What a beautiful, cool, gorgeous guy. If I was gay, I'd have a crush on him. Actually, I had a bit of a crush on him anyway. He played guitar brilliantly, his lyrics were amazing, he was gorgeous ... I wanted to be Pete. (The Guardian, 25 February 2005)

While 'heroic masculine imaginary positioning' was not the most dominant frame (cf. Wetherell and Edley 1999, p. 343), the above findings do support the claim 'that women do not enjoy the same mythologizing as their male counterparts, the gods, the kings, the shamans of rock' (Whiteley 2006, p. 334). In other words, broadsheet journalists do mobilize affiliating masculinities (homosociality), using Pete Doherty as an exemplar of hegemonic masculinity.

\section{All the men who are independent}

The third frame that is used more often to cover Pete Doherty (17\%) than Amy Winehouse $(7.5 \%)$ is the independent individual frame (Table 1). In these articles, the artists are described as independent and strong-willed individuals. However, these individualists generally live by their own set of rules without taking others into consideration, making their behavior 'wayward' (The Independent, 6 February 2005), 'unreliable' (The Independent, 23 August 2005), 'unchoreographed', or 'notoriously unpredictable' (The Guardian, 31 December2004). But whereas Winehouse's independent and individualist behavior is - again - merely reported on, British journalists seem to defend Doherty's conduct in various ways. First, several articles argue that his demeanor is inherently part of being an independent individual. 
'Pete is unmanageable. You cannot coerce him into anything he doesn't want to do. He is totally a free spirit.' (The Guardian, 31 December, 2004)

Second, Doherty's behavior is said to be the result of his complex character, consisting of multiple personalities, which makes him even more intriguing:

Who is that boy writing obsessively in his journal? That wayward lad with the razorquick wit and the impressions of Tony Hancock? I have a sneaking suspicion that Pete is all things to all men ... That's not to say he is a dishonest man, far from it, it's just that there are many Petes. (The Guardian, 27 August 2005)

Finally, some journalists deny that the 'real' Doherty is the 'irresponsible' or 'selfish' (The Independent, 23 August 2005) person depicted in the tabloids. On the contrary, he is a charming, funny, and even polite young man. This 'illusion of intimacy' - of knowing the truth about what a celebrity is really like (Meyers 2009) - also occurs in stories of Winehouse, but, in contrast to Doherty, she is not defended as such. Thus, Pete Doherty is not only more likely to be framed as an independent individual; the negative consequences of his rock and roll lifestyle are justified or

denied. Apparently, even broadsheet journalists see unpredictability - which strongly contrasts with the management rationality of business masculinity - as an integral part of the (masculine) artistic persona (cf. Leonard 2007).

\section{Authenticity and success}

Although previous studies have shown the importance of authenticity in popular music discourse - particularly for female artists (Schmutz and Faupel 2010), it does not play a significant role in our analyses nor does its use differ between Amy Winehouse (10.0\%) and Pete Doherty (2.1\%). The number of articles that discuss the success of both artists was limited and again did not differ significantly between Winehouse (5.0\%) and Doherty (10.6\%). This might be due to our selection of two highly successful artists. Furthermore, authenticity is often considered a prerequisite for artistic success. 


\section{Framing rock and fall}

\section{Cause for concern}

Whereas Pete Doherty is predominantly framed as an artist who dares to live on the edge, many journalists interpret similar behavior in Amy Winehouse as damaging, harmful, and unhealthy, particularly for the artist herself.5 This concern frame is the main topic in $27.5 \%$ of all articles about Winehouse compared to $8.5 \%$ in the case of Doherty (Table 1). In the case of the former, most articles stress the consequences of her alcohol and drug addiction. Journalists are 'concerned with her well-being' (The Guardian, 23 July 2007), whereas new incidents 'raise fresh concern' (The Guardian, 22 August 2007), even to a point where journalists 'no longer feel easy making jokes about it' (The Guardian, 29 August 2007).

Alarmingly thin and conspicuously drunk much of the time, the singer has recently cancelled several large gigs citing exhaustion, and has increasingly displayed an appetite for punkish self-destruction that has won her comparisons with Sid Vicious, the Sex Pistols bassist who died aged 21. 'She is obviously not happy and she obviously needs help!' (The Guardian, 17 August 2007)

Many journalists also refer to her physical appearance, describing her as 'stick thin' (The Guardian, 17 August 2007) with 'spindly little legs' (The Guardian, 14 September 2006). Supposedly, she is a 'self confessed depressive and sometime anorexic/bulimic' (The Independent, 20 February 2007). Furthermore, Winehouse is often said to have problems dealing with her fame, when she was 'catapulted to being a superstar' (The Guardian, 17 August 2007). Moreover, journalists - on a quest of 'saving Amy' (see Barak 2010) - focus on explicit paternalistic advice to take better care of herself and focus on her music (see Martin 2006, p. 263).

While the concern frame is less widely used in the case of Doherty, he is also described as looking unhealthy, not being able 'to stand straight' or to produce 'complete sentences' (The Guardian, 4 November 2005). However, where Winehouse needs help as a person not able to deal 
with fame, concern about Doherty's rock and roll lifestyle stands in his way to possible 'greatness' (The Independent, 29 May, 2004), such as: 'if Pete was not a junkie he would be 10 times bigger' (The Guardian, 31 December 2004). Thus, British broadsheets frame Doherty as much more in control, as an entrepreneur of the self, while Winehouse is more likely to be cast as $\mathrm{a}$ - albeit not that passive - victim in need of help, embodying what McRobbie (2009) has labeled the impossibility of post-feminist femininity.

\section{Stand and cannot deliver}

In addition to expressing concern, $7.5 \%$ of the newspaper articles describe how Amy Winehouse fails to deliver good shows as a result of her alcohol and drug addiction (Table 1). Such stories refer to her performance as 'slurred' (The Independent, 28 November 2007) or 'substandard' (The Guardian, 27 November 2007) and Winehouse herself as 'distracted' (The Guardian, 22 June 2007) and 'detached from the experience' (The Guardian, 22 June 2007):

Though Winehouse's live voice is flawless, she bares more than a passing resemblance of a rabbit caught in the headlights. It takes a few songs to shake off the nerves, but she never quite loses the slightly traumatized expression ... Her rigid expression is pretty distracting, as is her eyes rolling around in her sockets and her clenched jaw. But nerves can do that to a girl! (The Guardian, 22 June 2007)

Interestingly, we found no newspaper articles reporting primarily on how similar behavior affects Pete Doherty's musical achievements (Table 1). Broadsheet journalists seemingly frame such behavior as unproblematic for male - but not female - musicianship. Newspaper readers are invited to play the 'waiting game' to see when professionally accomplished - but personally troubled - female celebrities will collapse under the weight of relationship, family, and career (Negra and Holmes 2008, Williamson 2010).

Media victim, dependent individual, and crazy 
For both Amy Winehouse and Pete Doherty, we found only a few articles in which they were directly framed as media victims, $10.0 \%$ and $2.1 \%$, respectively. These stories often stress how the tabloids 'dig out the most uncomfortable details under the auspices of thorough reporting' (The Guardian, August 29 2007) and 'lurch from biggest groupies to most vicious detractors' (The Guardian, 15 December 2007). Broadsheet journalists - again - express their concern that Amy Winehouse cannot handle the schadenfreude of the tabloids, encouraging her alcohol and drug addiction (Shaw et al.2010, Tyler and Bennett 2010). Therefore she needs to be protected against such media attention, and broadsheet reporters urge the tabloids to focus on her music, instead of her private life.

The psychodrama of Winehouse's life has taken centre stage in a public discourse that should be celebrating her raw gift. (The Guardian, 18 July 2007)

Interestingly, the frequency with which broadsheets journalists draw on this frame does not differ significantly between Winehouse and Doherty (Table 1). And since only one article about Doherty stresses the media victim frame, we cannot draw any conclusions whether this frame was employed differently vis-à-vis Winehouse.

Only a few articles frame Amy Winehouse (7.5\%) and Pete Doherty (4.3\%) as dependent on girl- or boyfriend, family members, or musical partners. In the case of Doherty, both articles focus on his homosocial relationship with Libertines' co-founder Carl Barat. While journalists expected Doherty to fail without the support of the more straight-headed Barat, this was not the case, providing additional support for the independent individual frame:

It seemed obvious that without Carl Barat as foil and spur, Doherty's muse could only wreak a hollow kind of havoc. All of which makes tonight some kind of miracle. Doherty is a star. (The Guardian, 9 October 2004)

In addition, while Doherty was also in a turbulent relationship with model Kate Moss, he was never described as relying on her. While Winehouse is described as dependent on her husband Blake Fielder-Civil, he also is depicted as dependent on her. Several newspaper stories reported 
that they were always together and could not live without each other. One article cites Winehouse herself, explaining why she cancelled a concert:

I can't give it my all on stage without my Blake. I'm so sorry but I don't want to do the shows 'half-heartedly'; I love singing. My husband is everything to me and without him it's just not the same. (The Independent, 22 November 2007)

These findings seem to contradict earlier studies as journalists hardly ever frame both artists as dependent on others (Tuchman and Fortin 1984, Johnson-Grau 2002) or blame others as the source of their excessive behavior (Shaw et al.2010).

Finally, a few newspaper articles frame Amy Winehouse (7.5\%) and Pete Doherty (4.3\%) as plain crazy. Although Winehouse is sometimes mocked for her hairdo or for putting herself in embarrassing situations, we found few cases suggesting that 'rebellious and uncontained female celebrities are, by default, somehow insane' (Bell 2008, p. 5) as previous studies have suggested.

\section{Conclusion and discussion}

This article addresses to what extent and in what ways British broadsheet newspapers frame Pete Doherty and Amy Winehouse differently in relation to their rock and roll lifestyle. Our findings show that Pete Doherty is discussed much more positively (rock and roll) than Winehouse (rock and fall), confirming the suspicions and predictions of popular music scholars as well as recent studies on the gendered media coverage of celebrities. So while Winehouse's behavior is criticized by British broadsheet journalists, Doherty seems to 'get away' with his behavior.

Our research also provides valuable insights into how complicit masculinity operates in practice, that is, how intergender relationality plays out in the media framing of hegemonic masculinity. On the one hand, journalists reward (or at least condone) Pete Doherty for enacting a rock and roll lifestyle. First, they explicitly admire him - as an exemplar of hegemonic masculinity - for living on the edge and for being a hero, whose rock and roll lifestyle they - and their readers - fantasize about. Second, broadsheet journalists justify the negative side-effects of 
the rock and roll lifestyle as 'part of the deal' or, third, negate these effects as exaggerations of the tabloid press. On the other hand, female enactment of masculine behavior is not sanctioned in British broadsheets. Rather than framing Amy Winehouse as outright insane, journalists use a more 'ordinary' practice: victimization. Winehouse is considered a victim who needs to be saved, not solely from the barrage of (tabloid) media coverage, but primarily from her destructive self. Thus, admiration/justification/negation and victimization are relational complicit practices that often unreflexively - maintain the masculine monopoly over a prestigious form of expression: the archetypical rock and roll lifestyle. Further research is needed to test the extent to which our findings are generalizable to male and female artists in general.

In addition, our study shows that the behavior of Amy Winehouse and Pete Doherty is held accountable to rock masculinity. Yet, previous research suggests that business masculinity being in control instead of out of control - is more congruent with the normative conceptions of broadsheet readership. We offer two tentative explanations for why rock masculinity might resonate among the business elite as well (Eastman 2012). First, due to the global dominance of business masculinity, rock masculinity might function as a nostalgic refuge where masculinity is still - as in the 1960 s - constructed in terms of freedom from constraints, instead of technical rationality and managing the self. Indeed, according to Beynon (2002, p. 127), a lament for the demise of the 'old man' in comparison to the nebulous 'new man' is a recurring theme in broadsheet newspapers. Second, with the growing pervasiveness of celebrity culture and an increasingly competitive newspaper market, scandals about falling (female) stars are highly profitable commodities, both for media outlets as well as exemplary artists themselves. As a consequence, an increasing number of stakeholders might benefit from upholding the gender status quo. Future research might examine how this gendered process of celebrity production (including the role of digital media) affects rock masculinity.

Finally, while explaining the death of Amy Winehouse is beyond the scope of this study, she indeed seemed to embody the impossibility of post-feminist femininity, balancing between 
Girl Power and Reviving Ophelia (Gonick 2006), as suggested in the introduction. On the one hand, she was a successful individual performer who was not considered a passive media victim or dependent on others. On the other hand, Winehouse was framed as a falling or failing musician who could not deal with her success due to her own insecurity, resulting in (normalized) 'pathological' behavior. The normalcy of pathology is painfully evident from a third type of media reaction to her death:

It's the kind of story that usually only ends one way, and yet the reaction to her death, my own included, was one of shocked disbelief. Perhaps it's because the chaos of her life had been lived in full public view: it was hardly the first time that an ambulance had been called to her flat because of an overdose, but she'd always somehow survived. (The Guardian, 25 July 2011)

\section{Acknowledgements}

We would like to thank the anonymous reviewers and the editor for their excellent comments and suggestions for improvement to this article.

\section{Notes}

1. Previous studies have demonstrated that broadsheet newspapers do affect other media (such as TV news) - and as such most likely society in general, particularly by agenda-setting (Golan 2006). In addition, media scholars have also signaled an 'up-spill' of inter-media agenda-setting in which tabloids influence the topics discussed by broadsheets (Matthews and Brown 2011). However, measuring media effects is beyond the scope of this study.

2. For an elaborate overview and criticism of the concept, see Demetriou (2001) and Moller (2007). 
3. Our analyses hardly contain any articles written by female (pop or rock) journalists (cf. McLeod 2002). Future studies might examine their differences in relation to the description of artists.

4. In theory, differences in the use of particular frames that are found statistically not significant might still result from (qualitatively) different complicit mechanisms. In practice, however, such differences are primarily due to small numbers, making it difficult to draw a strong conclusion on how they are used.

5. Interestingly, none of the articles discusses whether both artists' behavior might set a 'wrong' example for their fans (see Sheridan et al.2007).

\section{References}

Barak, D., 2010. Saving Amy. London: New Holland.

Bell, E., 2008. From bad girl to mad girl: British female celebrity, reality products and the pathologization of pop-feminism. Genders [online], 48. Available from:

http://www.genders.org/g48/g48_bell.html [Accessed 12 May 2011].

Beynon, J., 2002. Masculinities and culture. Buckingham: Open University Press.

Binder, A., 1993. Constructing racial rhetoric: media depictions of harm in heavy metal and rap music. American sociological review, 58 (6), 753-767.

Bourdieu, P., 1993. The field of cultural production. Cambridge, UK: Polity Press.

Chan, T.W. and Goldthorpe, J.H., 2007. Social status and newspaper readership. American journal of sociology, 112 (4), 1095-1134.

Clawson, M.A., 1999. When women play the bass: instrument specialization and gender interpretation in alternative rock music. Gender \& society, 13 (2), 193210. 
Coates, N., 1997. (R)evolution now? rock and the political potential of gender. In: S. Whiteley, ed. Sexing the groove: popular music and gender. New York, NY: Routledge, 50-64.

Connell, R.W., 1995. Masculinities. 2nd edition. Cambridge, UK: Polity.

Connell, R.W., 1998. Masculinities and globalization. Men and masculinities, 1 (3), $3-23$.

Connell, R.W. and Messerschmidt, J.W., 2005. Hegemonic masculinity: rethinking the concept. Gender \& society, 19 (6), 829-859.

Connell, R.W. and Wood, J., 2005. Globalization and business masculinities. Men and masculinities, 7 (4), 347-364.

Davies, H., 2001. All rock and roll is homosocial: the representation of women in the British rock music press. Popular music, 20 (3), 301-319.

Demetriou, D., 2001. Connell's concept of hegemonic masculinity: a critique. Theory and society, 30, 337-361.

Eastman, J.T., 2012. Rebel manhood: The hegemonic masculinity of the Southern rock music revival. Journal of contemporary ethnography, 41 (2), 189-219.

Entman, R., 1993. Framing: toward clarification of a fractured paradigm. Journal of communication, 41 (4), 6-28.

Finley, N.J., 2010. Skating femininity: gender maneuvering in women's roller derby. Journal of contemporary ethnography, 39 (4), 359-387.

Frith, S., 1983. Sound effects: youth, leisure and the politics of rock'n'roll. New York, NY: Pantheon Books.

Frith, S. and McRobbie, A., 1990. Rock and sexuality. In: S. Frith and A. Goodwin, 
eds. On Record: rock, pop and the written word. London: Routledge, 371-389.

Gies, L., 2011. Stars behaving badly: inequality and transgression in celebrity culture. Feminist media studies, 11 (3), 347-361.

Golan, G., 2006. Inter-media agenda setting and global news coverage. Journalism studies, 7 (2), 323-333.

Gonick, M., 2006. Between "girl power" and "reviving Ophelia": constituting the neoliberal girl subject. NWSA journal, 18 (2), 1-23.

Grazian, D., 2007. The girl hunt: urban nightlife and the performance of masculinity as collective activity. Symbolic interaction, 30 (2), 221-243.

Gudmundsson, G., et al., 2002. Brit crit: turning points in British rock criticism, 1960-1990. In: S. Jones, ed. Pop music and the press. Philadelphia, PA: Temple University Press, 41-64.

Hannaford, A., 2007. Pete Doherty: last of the rock romantics. London: Ebury Press.

Iacuone, D., 2005. "Real men are tough guys": hegemonic masculinity and safety in the construction industry. The journal of men's studies, 13 (2), 247-266.

Janssen, S., Kuipers, G. and Verboord, M., 2008. Cultural globalization and arts journalism: the international orientation of arts and culture coverage in Dutch, German, French and US newspapers, 1955-2005. American sociological review, $73(5), 719-740$.

Jarman-Ivens, F., ed., 2007. Oh boy! Masculinities in popular music. New York, NY: Routledge.

Johnson-Grau, B., 2002. Sweet nothings: representation of women musicians in 
pop journalism. In: S. Jones, ed. Pop music and the press. Philadelphia, PA: Temple University Press, 202-218.

Kerfoot, D. and Knights, D., 1998. Managing masculinity in contemporary organizational life: a managerial project. Organization, 5 (1), 7-26.

Knoppers, A. and Anthonissen, A., 2005. Male athletic and managerial masculinities: congruencies in discursive practices? Journal of gender studies, 14 (2), 123135.

Leonard, M., 2007. Gender in the music industry: rock, discourse and girl power. London: Ashgate.

Martin, P.Y., 2001. 'Mobilizing masculinities': women's experiences of men at work. Organization, 8 (4), 587-618.

Martin, P.Y., 2003. "Said and done" versus "saying and doing": gendering practices, practicing gender at work. Gender \& society, 17 (3), 342-366.

Martin, P.Y., 2006. Practising gender at work: further thoughts on reflexivity. Gender, work \& organization, 13 (3), 254-276.

Matthews, J. and Brown, A., 2011. Negatively shaping the asylum agenda? The representational strategy and impact of a tabloid campaign. Journalism, 13 (8), 116.

McLeod, K., 2002. Between rock and a hard place: gender and rock criticism. In: S. Jones, ed. Pop music and the press. Philadelphia, PA: Temple University Press, 3113.

McRobbie, A., 2009. The aftermath of feminism: gender, culture and social change. London: Sage. 
Meyers, E., 2009. "Can you handle my truth? Authenticity and the celebrity star image. The journal of popular culture, 42 (5), 890-907.

Moller, M., 2007. Exploiting patterns: a critique of hegemonic masculinity. Journal of gender studies, 16 (3), 263-276.

Negra, D. and Holmes, S., 2008. Introduction. Genders [online], 48. Available from: http://www.genders.org/g48/g48_negraholmes.html [Accessed 10 May 2011].

Newkey-Burden, C., 2008. Amy Winehouse: the biography. London, John Blake.

Poggio, B., 2006. Outline of a theory of gender practices. Gender, work \& organization, $13(3), 225-233$.

Reynolds, S. and Press, J., 1995. The sex revolts: gender, rebellion, and rock ' $n$ ' roll. Cambridge, MA: Harvard University Press.

Schippers, M., 2002. Rockin' out the box: gender maneuvering in alternative rock. New Brunswick, NJ: Rutgers University Press.

Schippers, M., 2007. Recovering the feminine other: masculinity, femininity, and gender hegemony. Theory and society, 36, 85-102.

Schlesinger, P., 2006. Is there a crisis in British journalism? Media, culture \& society, 28 (2), 299-307.

Schmutz, V. and Faupel, A., 2010. Gender and cultural consecration in popular music. Social forces, 89 (2), 685-708.

Schrock, D. and Schwalbe, M., 2009. Men, masculinity, and manhood acts. Annual review of sociology, 35, 277-295.

Sedgwick, E.K., 1985. Between men: English literature and male homosocial desire. New York, NY: Columbia University Press. 
Shaw, R.L., Whitehead, C. and Giles, D.C., 2010. 'Crack down on the celebrity junkies': does media coverage of celebrity drug use pose a risk to young people? Health, risk \& society, 12 (6), 575-589.

Sheridan, L., et al., 2007. Celebrity worship, addiction and criminality. Psychology, crime and law, 13 (6), $559-571$.

Tuchman, G. and Fortin, N., 1984. Fame and misfortune: edging women out of the great literary tradition. The American journal of sociology, 90 (1), 72-96.

Turner, G., 2004. Understanding celebrity. Thousand Oaks, CA: Sage.

Tyler, I. and Bennett, B., 2010. 'Celebrity chav': fame, femininity and social class. European journal of cultural studies, 13 (3), 375-393.

Wedgwood, N., 2009. Connell's theory of masculinity. Journal of gender studies, 18 (4), 329-339.

West, C. and Zimmerman, D.H., 1987. Doing gender. Gender \& society, 1 (2), $125-$ 151.

West, C. and Zimmerman, D.H., 2009. Accounting for doing gender. Gender \& society, 23 (1), 112-122.

Wetherell, M. and Edley, N., 1999. Negotiating hegemonic masculinity: imaginary positions and psycho-discursive practices. Feminism and psychology, 9 (3), 335356.

Whiteley, S., 2006. The killing fields of popular music. In: S. Holmes and S. Redmond, eds. Framing celebrity: new directions in celebrity culture. New York, NY: Routledge, 329-342.

Williamson, M., 2010. Female celebrities and the media: the gendered denigration of 
the 'ordinary' celebrity. Celebrity studies, 1 (1), 118-120.

Yates, N. and Samson, P., 2005. Pete Doherty: on the edge. London: John Blake.

\section{Cited Sources}

The Guardian, 2004. Review: Pop: The debauched charm of Pete Doherty. The Guardian, 15 April, p. 28.

— 2004. Review: Pop: Pete Doherty tames his music. The Guardian, 9 October, p. 23.

— 2004. The Guardian profile: Pete Doherty. The Guardian, 31 December, p. 13.

— 2005. G2: The life of a Libertine: Pete Doherty is out on bail, facing charges of

blackmail and robbery. The Guardian, 25 February, p. 2.

_ 2005. The Guide: A very likely lad: Roger Pomphrey has spent the last year filming the circus that is Pete Doherty's life for a new BBC documentary. The Guardian, 27 August, p. 8.

— 2005. Film \& Music: Cover story: Wasted. In a rare interview, Babyshambles frontman

Pete Doherty talks to Simon Hattenstone about death, love and why he can't go a day without drugs. The Guardian, 4 November, p. 6.

_ 2006. Reviews: Pop: Amy Winehouse Bloomsbury Ballroom, London. The Guardian,14 September, p. 40.

— 2007. Review: Amy Winehouse. The Guardian, 22 June.

— 2007. Comment \& Debate: She's back to British soul: Amy Winehouse sits in a long, if broken, tradition of artists who made the genre their own. The Guardian, 18 July, p. 28.

— 2007. G2: Shortcuts: Hard times for Amy Winehouse, Britain's biggest female star. The Guardian , 23 July, p. 2.

— 2007. The Guardian profile: Amy Winehouse. The Guardian, 17 August, p. 17.

- 2007. Amy Winehouse postpones North American tour. The Guardian, 22 August, no page numbers. 
— 2007. Amy Winehouse snogs husband in St Lucia. The Guardian, 29 August, no page numbers.

— 2007. Amy Winehouse cancels rest of tour dates for 2007. The Guardian, 27 November, no page numbers.

_ 2007. The Guide: The gong show: Most resilient hair: Amy Winehouse. The Guardian, 15 December, p. 14.

— 2008. Review: Solo and sober, post-prison Doherty still fires his fans' affections. The Guardian, 14 July, p. 13.

_ 2011. G2: A losing game: Amy Winehouse had talent to burn and sang because she had to. The Guardian, 25 July, p. 6.

— 2011. There's a way to report celebrity deaths - and the way the media handled Amy Winehouse's death wasn't right. The Guardian, 27 July, p. 9.

The Independent, 2004. What a waster. The Independent, 29 May, p. 3.

- 2005. He went into the cells a pop star, he may come out a poet: Publishers scramble to sign troubled rocker Pete Doherty. The Independent, 6 February, p. 9.

— 2005. First night: Doherty embroiled in another shambles as music stops for onstage brawl with guitarist. The Independent, 23 February, p. 18.

— 2005. My year with Pete Doherty. The Independent, 23 August, p. 32 - 33.

_ 2006. Total shambles: The new clothing line from Pete Doherty (no, really). The Independent, 5 November, p. 2.

_ 2006. Total shambles: The new clothing line from Pete Doherty (no, really). The Independent, 5 November, p. 2.

_ 2007. The newqueen of pop: An audience with Amy Winehouse. The Independent, 20

February, p. 24.

- 2007. Winehouse faces the music as she cancels rest of tour. The Independent, 28

November, p. 10. 
— 2011. Razor sharp, she changed the music scene for ever. The Independent , 24 July, p.

48. 
Table

Table 1. Frames used in newspaper articles that discuss Winehouse and Doherty

\begin{tabular}{llll}
\hline Frames & Amy Winehouse & Pete Doherty & Sig. \\
\hline \multirow{2}{*}{ Rock and roll } & & & \\
Living on the edge & $17.5 \%(7)$ & $40.4 \%(19)$ & $*$ \\
Hero & $0.0 \%(0)$ & $10.6 \%(5)$ & $*$ \\
Independent individual & $7.5 \%(3)$ & $17.0 \%(8)$ & $\dagger$ \\
Authenticity & $10.0 \%(4)$ & $2.1 \%(1)$ & n.s. \\
Success & $5.0 \%(2)$ & $10.6 \%(5)$ & n.s. \\
Total Rock and roll & $40.0 \%(16)$ & $80.9 \%(38)$ & $* * *$ \\
& & & \\
Rock and fall & & $8.5 \%(4)$ & $*$ \\
Concern & $27.5 \%(11)$ & $0.0 \%(0)$ & $\dagger$ \\
Can not deliver & $7.5 \%(3)$ & $2.1 \%(1)$ & n.s. \\
Media victim & $10.0 \%(4)$ & $4.3 \%(2)$ & n.s. \\
Dependent individual & $7.5 \%(3)$ & $4.3 \%(2)$ & $* * *$ \\
Crazy & $7.5 \%(3)$ & $19.1 \%(9)$ & \\
Total Rock and fall & $60.0 \%(24)$ & & \\
& & $100 \%(47)$ & \\
Total & $100 \%(40)$ & & \\
\hline
\end{tabular}

$\dagger=p<0.1 ; *=p<0.05 ; * * p<0.01 ; * * *=p<0.001$, n.s. $=$ not significant 